and more frequent as car ownership increases. To discourage the practice of patients driving vehicles whilst wearing a limb plaster cast, it is suggested that there be added to the printed instructions routinely handed to " patients who have had a plaster-of-Paris applied" a paragraph, in the interests of road safety, calling attention to the section of the Road Traffic Act dealing with careless driving, as well as a note indicating that driving may damage the plaster. Notices about the Act could be displayed in eye clinics and waiting-rooms in hospitals, and also in general practitioners' surgeries.

Certainly with casts, cars are contraindicated, for as always a plastered driver is dangerous!-I am, etc.,

The Infirmary,

Kilmarnock, Ayrshire.

STEPHEN Young.

\section{Bone-marrow Hypoplasia}

SIR,-The recent paper "Bone-marrow Hypoplasia in the Course of Haemolytic Disease of the Newborn" by Drs. A. D. F. Hurdle and Anna G. Walker (February 23, p. 518) draws attention to the little-known fact that a type of hypoplastic anaemia, affecting the red cells, may occur in some of these cases. We have seen a case similar in many respects, but a diagnosis of erythrogenesis imperfecta was considered for a time in view of the prolonged hypoplastic anaemia and the bone-marrow picture.

The baby was born by normal delivery, following induction, at 38 weeks' gestation. The mother was group A $\mathrm{Rh}$-negative, and had had two previous pregnancies, the second baby being severely affected, requiring exchange transfusion. The husband was group A Rh-positive (probable genotype CDe-CDe, R1 R1). Antibodies detected by the indirect Coombs technique gave significant titres of 40 and 80 at 32 and 36 weeks of pregnancy respectively.

At birth the baby weighed $8 \mathrm{lb} .3 \mathrm{oz}$. $(3.7 \mathrm{~kg}$.) and had an enlarged liver and spleen. The cord haemoglobin was $14.8 \mathrm{~g} . / 100 \mathrm{ml}$., direct Coombs test strongly positive, and total serum bilirubin $5 \mathrm{mg} . / 100 \mathrm{ml}$. At no time did the bilirubin rise above $10 \mathrm{mg} . / 100 \mathrm{ml}$. After an exchange transfusion of $600 \mathrm{ml}$. group $\mathrm{O} \mathrm{Rh}$-negative blood, the heel prick haemoglobin fell to $8 \mathrm{~g} . / 100 \mathrm{ml}$. the following day, when a simple transfusion of $120 \mathrm{ml}$. blood was given (haemoglobin then 15.6 g. $/ 100 \mathrm{ml}$.).

Simple transfusion was repeated at 35 and 60 days after birth, when the haemoglobin was 8.4 and $7.4 \mathrm{~g} . / 100 \mathrm{ml}$ respectively. On the latter occasion bone-marrow examination (tibial crest) showed an intense normoblastic hyperplasia, with $47 \%$ normoblasts, mostly late forms. The reticulocyte count, seven days previously, was less than $1 \%$, total white cells 7,000 per c.mm. Only donor cells were demonstrable in the peripheral blood, and an adequate sample of the heparinized bone-marrow aspirate also failed to group

The post-transfusion haemoglobin again fell gradually to $10 \mathrm{~g} . / 100 \mathrm{ml}$. at 103 days after birth. Only then did the baby's blood begin to show a mixed population against anti-A serum and saline anti-D. Thereafter the haemoglobin started to rise very steadily to $12 \mathrm{~g} . / 100 \mathrm{ml}$. at 150 days.

This case, like that of Drs. Hurdle and Walker, and many other cases of haemolytic disease of the newborn, required simple transfusion at about 4 weeks of life. Had we not transfused at 9 weeks, the blood picture might well have recovered spontaneously. However, because of the degree of anaemia and the fact that its aetiology was uncertain, blood was given, possibly masking a spontaneous improvement at this stage and retarding the appearance of group A cells until the 14th week.

The bone-marrow appearances and hypoplastic peripheral blood picture may be interpreted as "maturation arrest" or as a defect in the release of red cells of " hypersplenic" type, rather than the direct action of antibody on marrow cells, presumably at a time when titres are insignificant. It must also be pointed out that the normoblastaemia noted at birth may be extramedullary in origin and is not an index of bone-marrow activity, though the fact remains that these babies become more anaemic soon after birth at a time when marrow hypoplasia normally becomes apparent. It is of interest that this baby's affected sibling showed a similar persisting anaemia requiring three simple transfusions, the last one at 9 weeks of life, in another hospital. Unfortunately this fact did not come to light until a later date, otherwise it might have saved us a great deal of anxiety about the outcome of the present case. Both children are now normal in all respects.I am, etc.,

\section{Liverpool Maternity Hospital,}

Liverpool 7.

\section{Indications for Tonsillectomy}

SIR,- - The correspondence on indications for tonsillectomy, started by Dr. Violet P. Spiller's very sensible letter (March 23, p. 820), has brought out once again the familiar fact that the results of surgery on tonsils and adenoids vary from very good to very bad. This is hardly surprising when it is considered that the surgery itself has the same variations-in some cases these strange structures being treated with the same care and delicacy they would receive if they lay inside the chest rather than inside the naso-pharynx, while in an unknown percentage of others they are attacked blindly and hurriedly according to a tradition of surgery that has been long given up elsewhere.

There are similar variations in their descriptions in textbooks; the inquirer can take his choice as to whether the tonsils have six arteries of supply or only one ; while the adenoids are to all intents and purposes not described at all. The result is that the surgical attack on them fails in about $20-30 \%$ of cases, so making any assessment of their value to the human body quite impossible clinically.-I am, etc.

London W.1.

Denis Browne.

\section{Typhoid in Zermatt}

SIR,--The existence of rapidly flowing rivers present to the sanitary engineer an easy method of disposal of sewage, garbage, and other waste. Some years ago I stood on the banks of the Aare at Berne and watched many pieces of paper being carried swiftly along it. It was only after some seconds that I realized the significance of this.

I have spent not less than 40 of the most delightful holidays of my life in Switzerland and have been much impressed by the quality of the curative medical work and hospitals there. The sanitation in the larger towns has seemed to me excellent, as has also that in the Bernese Oberland and other regions north of the Rhone valley, but in the valleys extending south from the Rhone towards the Italian border things have appeared to be much less satisfactory.

A few years ago at Arolla I saw foul-smelling sewage oozing from a bank and flowing over the footpath. In Zermatt my wife and I each drank a glass of fresh milk at a little restaurant when walking down a mule track from the Schwarzsee. Severe diarrhoea followed in both cases. After that we decided never to drink unboiled milk again in Switzerland but in future to 